\title{
BIOPROSPEKSI KAPANG YANG BERASOSIASI DENGAN BIOTALAUT ASAL KEPULAUAN SERIBU SEBAGAI ANTITUMOR T47D DAN HepG2
}

\section{Bioprospecting of Fungi Associated with Marine Biota from Kepulauan Seribu as Antitumor T47D and HepG2}

\author{
Nurrahmi Dewi Fajarningsih ${ }^{1 *}$, Asri Pratitis ${ }^{1}$, Thamrin Wikanta' ${ }^{1}$, dan Ekowati Chasanah ${ }^{1}$ \\ ${ }^{1}$ Peneliti pada Balai Besar Penelitian dan Pengembangan Pengolahan Produk dan Bioteknologi Kelautan dan Perikanan, \\ Balitbang KP, KKP \\ "Korespondensi Penulis: Nurrahmi Dewi Fajarningsih, JI. K.S. Tubun Petamburan VI, Jakarta Pusat 10260. \\ E-mail: nurrahmi_dewi@yahoo.com
}

\begin{abstract}
ABSTRAK
Kapang laut menjadi sumber yang menjanjikan dalam pencarian senyawa antitumor baru. Penelitian ini bertujuan untuk mengisolasi kapang yang berasosiasi dengan spons dan karang lunak asal Taman Nasional Laut Kepulauan Seribu dan menguji prospek isolat-isolat tersebut sebagai penghasil senyawa bioaktif antitumor payudara (T47D) dan antitumor liver (HepG2). Sejumlah 46 isolat kapang telah diisolasi dari 17 sampel spons dan karang lunak dengan menggunakan media isolasi Malt Extract Agar (MEA), Glucose Peptone Yeast (GPY) dan Minimal Fungal Medium (MFM). Masing-masing isolat kapang dikultur dalam media cair $(100 \mathrm{~mL})$ selama 4 minggu pada suhu ruang $\left(27-28^{\circ} \mathrm{C}\right)$ dalam kondisi statis. Ekstrak kasar dari tiap isolat kapang selanjutnya diuji aktivitas sitotoksiknya terhadap sel tumor payudara (T47D) dan sel tumor liver (HepG2) pada konsentrasi $30 \mu \mathrm{g} / \mathrm{mL}$ dengan metode uji MTT. Terdapat 6 isolat kapang yang aktif sebagai antitumor payudara (T47D), yaitu isolat MFP $42(42,28 \%)$, MFP $48(52,36 \%)$, MFP 49 (44,83\%), MFP $59(47,5 \%)$, MFP 60 (44,12\%), MFP 65 (41,27\%), MFP $70(40,21 \%)$ dan terdapat 1 isolat kapang (MFP 64) yang selain aktif sebagai antitumor payudara/T47D $(43,85 \%)$ juga aktif sebagai antitumor liver/HepG2 (40,22\%).
\end{abstract}

KATA KUNCI: antitumor, bioprospeksi, HepG2, kapang, biota laut, T47D

\begin{abstract}
Marine fungi has become a promising source in the search for new antitumor compounds. This study aims to isolate marine fungi associated with sponges and soft corals from Kepulauan Seribu Marine National Park and to examine the prospects of these isolates as producers of anti breast-tumor T47D and anti liver-tumor HepG2 agents. A number of 46 isolates of fungi were isolated from 17 samples of sponges and soft corals using isolation medium of Malt Extract Agar (MEA), Glucose Peptone Yeast (GPY) and Minimal Fungal Medium (MFM). Isolates of the fungi were cultured in liquid medium $(100 \mathrm{~mL})$ for 4 weeks at room temperature $\left(27-28^{\circ} \mathrm{C}\right)$ in static conditions. Crude extract of each isolate was then tested against breast tumor cells (T47D) and liver tumor cells (HepG2) at a concentration of $30 \mu \mathrm{g} / \mathrm{mL}$ using MTT assay method. There were 6 isolates of the fungi that considered active as anti breast-tumor (T47D), i.e. MFP 42 (42.28\%), MFP 48 (52.36\%), MFP 49 (44.83\%), MFP 59 (47.5\%), MFP 60 (44.12\%), MFP 65 (41.27\%), MFP 70 (40.21\%) and 1 isolate (MFP 64) was active as both anti breast-tumor T47D (43.85\%) and anti liver-tumor HepG2 (40.22\%).
\end{abstract}

KEYWORDS: antitumor, bioprospecting, HepG2, fungi, marine biota, T47D

\section{PENDAHULUAN}

Pencarian senyawa bioaktif baru sebagai kandidat obat menjadi salah satu tujuan penting industri farmasi (Bhatnagar \& Kim, 2010). Berbagai penelitian telah membuktikan hipotesa bahwa produksi senyawa metabolit sekunder oleh suatu organisme tidak bersifat acak, namun sangat dipengaruhi oleh niche ekologis (habitat spesifik) (Gloer, 1997 dalam Holler et al., 2000). Dengan alasan tersebut, banyak peneliti di dunia menjadi lebih tertarik untuk meneliti organisme laut dibandingkan organisme darat yang telah lama dieksplorasi dalam upaya untuk mendapatkan senyawa bioaktif baru (Holler et al., 2000; Schulz et al., 2008). 
Mikroba laut, khususnya kapang, menjadi sumber penting untuk mendapatkan senyawa baru dengan aktivitas farmakologis potensial (Kjer et al., 2010). Kapang yang diisolasi dari lingkungan laut menghasilkan keanekaragaman metabolit sekunder yang tinggi. Sekitar $38 \%$ dari 22.000 senyawa bioaktif yang diisolasi dari mikroba berasal dari kapang (Berdy, 2005). Dalam review yang ditulis oleh Bugni \& Ireland (2004), setidaknya terdapat 273 struktur kimia baru yang berhasil diisolasi dari kapang laut.

Kapang laut terbukti menjadi sumber yang menjanjikan dalam pencarian senyawa antikanker, antibakteri, antiviral, anti-inflamasi, dan berbagai senyawa bioaktif lain (Bhadury et al., 2006). Senyawa alkaloid sorbicillactone A merupakan senyawa aktif antileukemia yang dihasilkan oleh kapang laut Penicillium chrysogenum. Kapang Penicillium chrysogenum sebelumnya diisolasi dari spons laut Ircinia fasciculate (Bhatnagar \& Kim, 2010). Senyawa aktif sorbicillactone A mampu membunuh sel kanker leukemia tanpa menunjukkan angka sitotoksisitas yang tinggi terhadap sel normal, atau bersifat selektif terhadap sel leukemia sehingga memenuhi syarat untuk diujikan pada manusia (Kjer et al., 2010). Selain itu, terdapat pula beberapa senyawa aktif antikanker yang diisolasi dari kapang yang bersimbion dengan berbagai rumput laut, di antaranya senyawa Sargassamide, halimide, dan avrainvillamide yang dapat menghambat pertumbuhan sel tumor lestari tipe tertentu (selektif) dan mempunyai aktivitas yang tinggi pada uji in vivo menggunakan model P-388 leukemia limfotik (Bhadury et al., 2006). Sementara itu, Chasanah et al. (2009) melaporkan ekstrak kapang jenis Exserohilum rostratum yang diisolasi dari spons laut asal Lombok memiliki aktivitas sitotoksik yang tinggi ketika diujikan terhadap sel tumor $\mathrm{H} 460$ (paruparu), MCF-7 (payudara) dan SF268 (otak). Nursid et al. (2011) juga melaporkan kapang jenis Emericella nidulans yang diisolasi dari ascidia Aplidium longitorax asal perairan Wakatobi menghasilkan senyawa aktif emestrin diketopieperazine yang mempunyai aktivitas sebagai antikanker T47D (payudara) melalui mekanisme apoptosis.

Hingga saat ini, penelitian-penelitian bioprospeksi kapang yang berasosiasi dengan biota laut di Indonesia masih sangat terbatas. Di sisi lain, Indonesia memiliki kekayaan biodiversitas laut yang sangat besar untuk dimanfaatkan dalam penelitianpenelitian bioprospeksi. Taman Nasional Laut (TNL) Kepulauan Seribu merupakan salah satu kawasan pelestarian alam bahari di Indonesia yang kaya akan biodiversitas laut. Namun, hingga saat ini kegiatan bioprospeksi untuk mengungkap potensi pemanfaatan kekayaan hayati laut TNL Kepulauan Seribu tersebut, misalnya sebagai penghasil senyawa antitumor, masih sangat terbatas.
Dalam data global cancer statistics (GLOBOCAN) 2008 yang diterbitkan oleh International Agency for Research on Cancer (IARC) WHO, sekitar $56 \%$ kasus kanker baru di dunia terjadi di negara berkembang dan $63 \%$ kematian yang diakibatkan oleh kanker juga terjadi di negara berkembang (Anon., 2012). Dalam data GLOBOCAN tahun 2008 tersebut diinformasikan bahwa kanker payudara merupakan jenis kanker dengan angka kejadian baru tertinggi (39.831 kasus) di Indonesia. Selain itu, kanker payudara juga menjadi penyebab kematian akibat kanker terbesar (20.052 kasus) di Indonesia. Selain kanker payudara, salah satu penyebab kematian yang signifikan adalah kanker liver. Pada tahun 2008, angka kejadian baru kanker liver di Indonesia mencapai 13.238 kasus, dengan angka kematian akibat kanker ini mencapai angka 12.825 kasus. Besarnya angka kematian akibat kanker tersebut menunjukkan bahwa berbagai terapi kanker yang ada saat ini masih belum efektif. Oleh karena itu, pencarian senyawa antitumor baru dengan potensi farmakologis yang baik sangat diperlukan.

Penelitian bioprospeksi ini bertujuan untuk mengisolasi kapang yang berasosiasi dengan biota laut asal TNL kepulauan Seribu serta untuk mendapatkan informasi mengenai potensi isolat-isolat kapang tersebut sebagai penghasil senyawa bioaktif antitumor payudara (T47D) dan antitumor liver (HepG2).

\section{BAHAN DAN METODE}

\section{Pengambilan Sampel Spons dan Karang Lunak}

Sebanyak 17 sampel spons dan karang lunak dari terumbu karang perairan Taman Nasional Laut Kepulauan Seribu diambil dengan scuba diving pada kedalaman $12 \mathrm{~m}$. Lokasi sampling berada pada koordinat S 5॰40'18.60", E 106³4'48.2", di sekitar Pulau Opak Besar. Sampel biota laut yang diperoleh dibersihkan dari kotoran yang menempel menggunakan air laut steril, selanjutnya dimasukkan ke dalam plastik steril, diberi label dan disimpan dalam cool box yang berisi es kemudian dibawa ke Laboratorium Bioteknologi, Balai Besar Penelitian dan Pengembangan Pengolahan Produk dan Bioteknologi Kelautan dan Perikanan (BBP4BKP) di Jakarta.

\section{Isolasi Kapang yang Berasosiasi dengan Sampel Spons dan Karang Lunak}

Isolasi kapang dilakukan dengan menggunakan tiga jenis media padat untuk isolasi, yaitu media Malt Extract Agar (MEA) yang mengandung 0,3\% malt extract, $0,3 \%$ yeast extract, $0,5 \%$ pepton, $1,5 \%$ agar, Minimal Fungal Medium (MFM) yang mengandung 
$0,02 \%$ yeast extract, $0,1 \%$ soluble starch, $2 \%$ agar, dan Glucose Peptone Yeast (GPY) yang mengandung $0,1 \%$ glucose monohydrate, $0,05 \%$ soybean peptone, $0,01 \%$ yeast extract, $1,5 \%$ agar. Ketiga jenis media tersebut dilarutkan dalam air laut buatan (artificial sea water/ASW), kemudian disterilisasi pada suhu $121^{\circ} \mathrm{C}$ selama 15 menit. Setelah sterilisasi, media dituang ke dalam cawan petri secara aseptis dan dibiarkan sampai menjadi padat.

Sebanyak 17 sampel biota laut (kode PS-201101; -02; -03; -04, -05; -06; -07; -08; -09; -10; -11; -12; $-13 ;-14 ;-16 ;-17$; dan -18) dipotong-potong menjadi beberapa bagian kecil (diiris tipis dengan menggunakan scalpel) secara aseptis. Potonganpotongan sampel tersebut kemudian diinokulasikan dalam 3 media berbeda yang telah dipersiapkan, yaitu MEA, MFM, dan GPY. Setelah diinkubasikan selama 3-5 hari pada suhu ruang, setiap kapang dengan morfologi berbeda yang tumbuh pada potongan sampel tersebut diisolasi dengan ditumbuhkan pada media baru yang sama dengan media asalnya hingga diperoleh isolat kapang tunggal.

\section{Kultivasi Isolat Kapang Tunggal}

Isolat kapang tunggal yang diperoleh pada tahap isolasi kemudian dikultur pada media cair yang sama dengan medium isolasinya, yaitu medium Malt Extract Broth (MEB) yang mengandung 0,3\% malt extract, $0,3 \%$ yeast extract, $0,5 \%$ pepton, medium GPY yang mengandung $0,1 \%$ glucose monohydrate; $0,05 \%$ soybean peptone; $0,01 \%$ yeast extract atau medium MFM yang mengandung $0,02 \%$ yeast extract; $0,1 \%$ soluble starch. Selanjutnya, media agar yang ditumbuhi kapang dipotong seukuran $1 \times 1 \mathrm{~cm}^{2}$ secara aseptis, kemudian dimasukkan ke dalam media kultur cair $10 \mathrm{~mL}$ dan diinkubasi pada suhu ruang selama 3 hari. Selanjutnya, isolat yang ditumbuhkan pada skala $10 \mathrm{~mL}$ tersebut dipindahkan seluruhnya secara aseptis pada media kultur yang sejenis pada skala yang lebih besar $(100 \mathrm{~mL})$. Kultivasi kapang skala $100 \mathrm{~mL}$ tersebut kemudian diinkubasi pada suhu ruang selama 4-5 minggu.

\section{Ekstraksi Senyawa Aktif dari Isolat Kapang Tunggal}

Isolat kapang tunggal yang telah ditumbuhkan selama 4-5 minggu, selanjutnya dimaserasi dengan pelarut etil asetat PA dengan perbandingan $2: 1$ (200 $\mathrm{mL}$ etil asetat: $100 \mathrm{~mL}$ media kapang). Setelah dimaserasi semalam, miselium kapang tersebut kemudian dipecah menggunakan sonikator (Sonics Vibra Cell) selama 5 menit dengan amplitudo $81 \%$. Selanjutnya, ekstrak etil asetat kapang dipisahkan dari media kultur menggunakan labu pemisah. Pelarut etil asetat kemudian diuapkan dengan rotary evaporator (Buchi) hingga diperoleh ekstrak kasar etil asetat. Selanjutnya, ekstrak kasar etil asetat yang dihasilkan diuji bioaktivitas antitumornya secara in vitro.

\section{Uji Bioaktivitas Antitumor in Vitro}

Uji antitumor dilakukan dengan menggunakan metode uji MTT menurut Zachary (2003) yang dimodifikasi. Sel tumor payudara T47D dan sel tumor liver HepG2 dikultur dalam media RPMI 1640 yang mengandung Fetal Bovine Serum (FBS) 10\%; fungizone 0,5\%; dan Penisilin-Streptomisin 2\%. Sebanyak 20.000 sel tumor T47D dan HepG2 (dalam $100 \mu \mathrm{L}$ media RPMI) dimasukkan ke dalam sumuran mikroplat, kemudian diinkubasi selama 24 jam. Sampel ekstrak kasar etil asetat kapang tunggal diujikan pada konsentrasi $30 \mu \mathrm{g} / \mathrm{mL}$, masing-masing sebanyak 3 kali ulangan. Selain sampel, dibuat pula 3 macam kontrol, yaitu: kontrol sel tumor, kontrol media (media saja tanpa sel tumor), dan kontrol sampel (sampel saja tanpa sel tumor). Sebelum sampel tersebut diujikan, media pertumbuhan sel dikeluarkan terlebih dahulu dari sumuran mikroplat. Sebanyak $100 \mu \mathrm{L}$ sampel ekstrak kasar kapang (30 $\mu \mathrm{g} / \mathrm{mL}$ ) dimasukkan ke dalam sumuran mikroplat yang telah berisi sel tumor yang telah melekat di dasar sumuran mikroplat. Kemudian mikroplat tersebut diinkubasi dalam inkubator $\mathrm{CO}_{2}$ pada suhu $37^{\circ} \mathrm{C}$ dengan aliran $\mathrm{CO}_{2} 5 \%$ selama 24 jam. Larutan sampel kemudian dikeluarkan dari tiap sumuran mikroplat, kemudian sebanyak $100 \mu \mathrm{L}$ reagen MTT (500 ppm) ditambahkan ke dalam tiap sumuran dan diinkubasikan kembali selama 4 jam dalam inkubator $\mathrm{CO}_{2}$. Reaksi MTT dihentikan dengan penambahan 100 $\mu \mathrm{L}$ sodium dodesil sulfat (SDS) $10 \%$. Selanjutnya, mikroplat kembali diinkubasikan selama 12 jam dalam ruang gelap pada suhu kamar. Setelah inkubasi tersebut, absorbansi tiap sumuran diukur dengan DYNEX spektrofotometer microplate reader pada panjang gelombang $570 \mathrm{~nm}$. Uji dilakukan secara duplo. Penentuan persentase kematian sel dihitung berdasarkan rumus:

$$
\% \text { Mortalitas }=\frac{(A-D)-(B-C)}{(A-D)} \times 100 \%
$$

Keterangan : $A=$ Absorbansi kontrol sel tumor, $\mathrm{B}=$ Absorbansi sampel, $\mathrm{C}=$ Absorbansi kontrol sampel, $\mathrm{D}=$ Absorbansi kontrol media 


\section{HASIL DAN BAHASAN}

\section{Isolat Kapang yang Berasosiasi dengan Spons dan Karang Lunak asal TNL. Kepulauan Seribu}

Sebanyak 46 isolat kapang berhasil diisolasi dari 17 sampel spons dan karang lunak asal Taman
Nasional Laut Kepulauan Seribu. Isolat-isolat tersebut ditampilkan pada Tabel 1. Penggunaan tiga jenis media yang berbeda dimaksudkan untuk mendapatkan jenis isolat kapang yang lebih banyak. Isolat kapang terbanyak (19 isolat) berhasil diisolasi dari media MEA, yang merupakan media dengan kandungan nutrisi paling kaya dibandingkan media MFM yang

Tabel 1. Isolat kapang yang diisolasi dari spons dan karang lunak asal TNL Kep. Seribu

Table 1. Marine-derived fungi isolated from sponges and soft corals from Kepulauan Seribu Marine National Parks

\begin{tabular}{|c|c|c|c|c|c|}
\hline No & $\begin{array}{l}\text { Isolat/ } \\
\text { Isolates }\end{array}$ & $\begin{array}{l}\text { Hospesl } \\
\text { Host }\end{array}$ & $\begin{array}{c}\text { Jenis Hospes/ } \\
\text { Type of Host }\end{array}$ & $\begin{array}{c}\text { Media Isolasi/ } \\
\text { Isolation medium }\end{array}$ & $\begin{array}{l}\text { Rendemen Ekstrak Kasarl } \\
\text { Crude Extract Yield (mg) }\end{array}$ \\
\hline 1 & MFP-26 & PS-2011-03 & Spons/Sponge & MEA & 88.5 \\
\hline 2 & MFP-28 & PS-2011-03 & Spons/Sponge & GPY & 97.7 \\
\hline 3 & MFP-29 & PS-2011-05 & Spons/Sponge & MEA & 89.1 \\
\hline 4 & MFP-30 & PS-2011-05 & Spons/Sponge & MFM & 45.4 \\
\hline 5 & MFP-31 & PS-2011-06 & Spons/Sponge & MEA & 112.6 \\
\hline 6 & MFP-32 & PS-2011-06 & Spons/Sponge & MEA & 83.1 \\
\hline 7 & MFP-33 & PS-2011-06 & Spons/Sponge & MEA & 26.8 \\
\hline 8 & MFP-34 & PS-2011-06 & Spons/Sponge & MFM & 53.8 \\
\hline 9 & MFP-35 & PS-2011-06 & Spons/Sponge & MFM & 112.1 \\
\hline 10 & MFP-36 & PS-2011-07 & Spons/Sponge & MEA & 105.7 \\
\hline 11 & MFP-37 & PS-2011-07 & Spons/Sponge & MEA & 137.5 \\
\hline 12 & MFP-38 & PS-2011-07 & Spons/Sponge & MEA & 73.9 \\
\hline 13 & MFP-39 & PS-2011-07 & Spons/Sponge & MFM & 89.5 \\
\hline 14 & MFP-42 & PS-2011-07 & Spons/Sponge & GPY & 109.5 \\
\hline 15 & MFP-43 & PS-2011-02 & Spons/Sponge & MEA & 99.0 \\
\hline 16 & MFP-45 & PS-2011-04 & Spons/Sponge & GPY & 24.5 \\
\hline 17 & MFP-47 & PS-2011-11 & Spons/Sponge & MFM & 55.4 \\
\hline 18 & MFP-48 & PS-2011-12 & Karang lunak/S oft & MFM & 68.6 \\
\hline 19 & MFP-49 & PS-2011-13 & Spons/Sponge & MFM & 66.4 \\
\hline 20 & MFP-50 & PS-2011-08 & Spons/Sponge & GPY & 106.9 \\
\hline 21 & MFP-51 & PS-2011-09 & Spons/Sponge & GPY & 61.0 \\
\hline 22 & MFP-52 & PS-2011-11 & Spons/Sponge & GPY & 34.8 \\
\hline 23 & MFP-53 & PS-2011-12 & Karang lunak/S oft & GPY & 101.9 \\
\hline 24 & MFP-54 & PS-2011-14 & Spons/Sponge & GPY & 86.4 \\
\hline 25 & MFP-55 & PS-2011-14 & Spons/Sponge & GPY & 94.9 \\
\hline 26 & MFP-56 & PS-2011-08 & Spons/Sponge & MEA & 66.4 \\
\hline 27 & MFP-57 & PS-2011-09 & Spons/Sponge & MEA & 70.3 \\
\hline 28 & MFP-59 & $P S-2011-10$ & Karang lunak/S oft & MEA & 60.7 \\
\hline 29 & MFP-60 & PS-2011-11 & Spons/Sponge & MEA & 98.1 \\
\hline 30 & MFP-61 & PS-2011-13 & Spons/Sponge & $M E A$ & 62.0 \\
\hline 31 & MFP-62 & PS-2011-13 & Spons/Sponge & MEA & 83.7 \\
\hline 32 & MFP-63 & PS-2011-14 & Spons/Sponge & $M E A$ & 63.7 \\
\hline 33 & MFP-64 & PS-2011-14 & Spons/Sponge & MEA & 104.6 \\
\hline 34 & MFP-65 & PS-2011-14 & Spons/Sponge & MEA & 86.3 \\
\hline 35 & MFP-66 & PS-2011-17 & Spons/Sponge & MEA & 91.9 \\
\hline 36 & MFP-67 & PS-2011-09 & Spons/Sponge & MFM & 49.8 \\
\hline 37 & MFP-68 & PS-2011-10 & Karang lunak/S oft & MFM & 57.6 \\
\hline 38 & MFP-69 & PS-2011-12 & Karang lunak/S oft & MFM & 41.7 \\
\hline 39 & MFP-70 & PS-2011-13 & Spons/Sponge & MFM & 35.1 \\
\hline 40 & MFP-71 & PS-2011-13 & Spons/Sponge & MFM & 33.5 \\
\hline 41 & MFP-72 & PS-2011-16 & Karang lunak/Soft & MFM & 26.7 \\
\hline 42 & MFP-73 & PS-2011-04 & Spons/Sponge & GPY & 46.8 \\
\hline 43 & MFP-74 & PS-2011-13 & Spons/Sponge & GPY & 39.8 \\
\hline 44 & MFP-75 & PS-2011-12 & Karang lunak/Soft & GPY & 49.5 \\
\hline 45 & MFP-76 & $P S-2011-10$ & Karang lunak/S oft & GPY & 52.6 \\
\hline 46 & MFP-77 & PS -2011-12 & Karang lunak/S oft & GPY & 38.8 \\
\hline
\end{tabular}


menghasilkan 15 isolat dan media GPY yang menghasilkan 12 isolat.

Rendemen ekstrak kasar dari 46 isolat kapang berkisar antara $24,5 \mathrm{mg}$ (isolat MFP 45 dalam media GPY) hingga 137,5 mg (isolat MFP 37 dalam media MEB), dengan rata-rata berat ekstrak kasar dari keseluruhan isolat kapang sebesar 73,0 mg. Ratarata berat esktrak kasar isolat kapang MFP yang dikultur dalam media MEB $(85,005 \mathrm{mg})$ lebih tinggi dibandingkan rata-rata berat esktrak kasar isolat kapang yang dikultur dalam media GPY $(72,33 \mathrm{mg})$ dan MFM (56,68 mg). Setiap jenis isolat kapang memiliki laju produksi biomassa yang berbeda sehingga berat ekstrak kasar yang dihasilkan juga berbeda. Selain itu, jenis isolat kapang yang sama apabila ditumbuhkan pada media berbeda akan menghasilkan berat ekstrak yang berbeda pula.

Media MEB mengandung 0,3\% malt extract sebagai sumber karbohidrat, $0,3 \%$ yeast extract sebagai sumber asam amino dan nitrogen, serta 0,5\% pepton sebagai sumber asam amino, peptida, dan protein sehingga media MEB menyediakan nutrisi yang lengkap untuk pertumbuhan optimum kapang. Sementara itu, media GPY dan MFM memiliki kandungan nutrisi yang jauh lebih sedikit dibandingkan dengan media MEB, yang menyebabkan pertumbuhan kapang di kedua media tersebut tidak seoptimal pertumbuhan kapang di media MEB. Media GPY hanya mengandung $0,1 \%$ glukosa sebagai sumber karbohidrat, $0,05 \%$ soybean peptone dan $0,01 \%$ yeast extract sebagai sumber asam amino dan protein; sedangkan media MFM hanya mengandung $0,02 \%$ yeast extract dan $0,1 \%$ soluble starch. Akibatnya, produksi biomassa kapang yang ditumbuhkan di media MEB lebih tinggi dibandingkan di media GPY dan MFM. Hasil penelitian Pratitis et al. (2010) menunjukkan bahwa isolat kapang

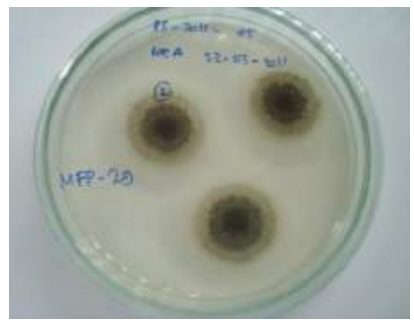

A

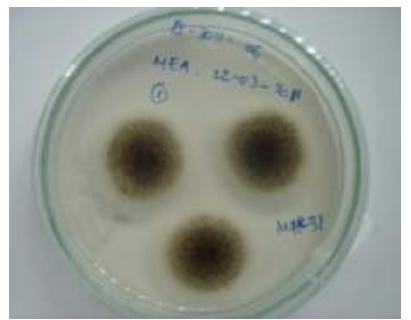

B

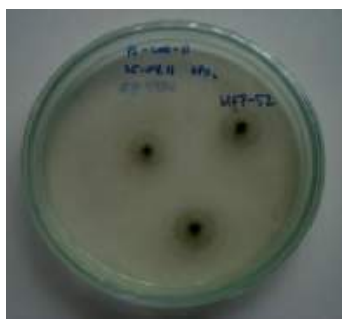

C

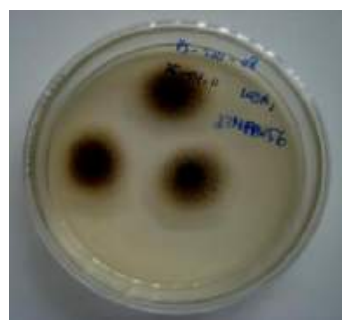

D

Gambar 1. Morfologi isolat Aspergillus ustus A. MFP-29 diisolasi dari spons PS-2011-05 pada media MEA, B. MFP-31 diisolasi dari spons PS-2011-06 pada media MEA, C. MFP-52 diisolasi dari spons PS-2011-11 pada media GPY, dan D. MFP-56 diisolasi dari spons PS-2011-08 pada media MEA

Figure 1. Morphology of Aspergillus ustus isolate A. MFP-29 isolated from PS-2011-05 sponge on MEA medium, B. MFP-31 isolated from PS-2011-06 sponge on MEA medium, C. MFP-52 isolated from PS-2011-11 sponge on GPY medium and D. MFP-56 isolated from PS-2011-08 sponge on MEA medium. 
yang ditumbuhkan pada media lain. Ekstrak $A$. ustus MFW 26-08 yang dikultur pada media MFM pada konsentrasi uji $30 \mu \mathrm{g} / \mathrm{mL}$ menyebabkan $89 \%$ kematian sel tumor T47D sedangkan yang dikultur pada media GPY dan MEB masing-masing menyebabkan kematian sel tumor T47D masing-masing sebesar $68 \%$ dan $13 \%$.

Dengan mempertimbangkan teori "OSMAC", maka seluruh isolat kapang MFP (46 isolat) yang didapatkan, termasuk isolat-isolat yang diduga berjenis sama, kemudian dikultur pada media cair skala $100 \mathrm{~mL}$ yang sama dengan media isolasinya. Kultur dalam skala $100 \mathrm{~mL}$ diperlukan untuk mendapatkan ekstrak kasar kapang dalam jumlah yang cukup untuk uji bioaktivitas antitumor.

\section{Bioaktivitas ekstrak kasar kapang}

Tahapan penapisan (screening) merupakan salah satu tahapan kritis pada penelitian pemanfaatan senyawa bioaktif dari bahan alam, maka validitas data pengujian bioaktivitas harus baik. Dengan demikian isolat kapang yang terpilih untuk diteliti lebih lanjut

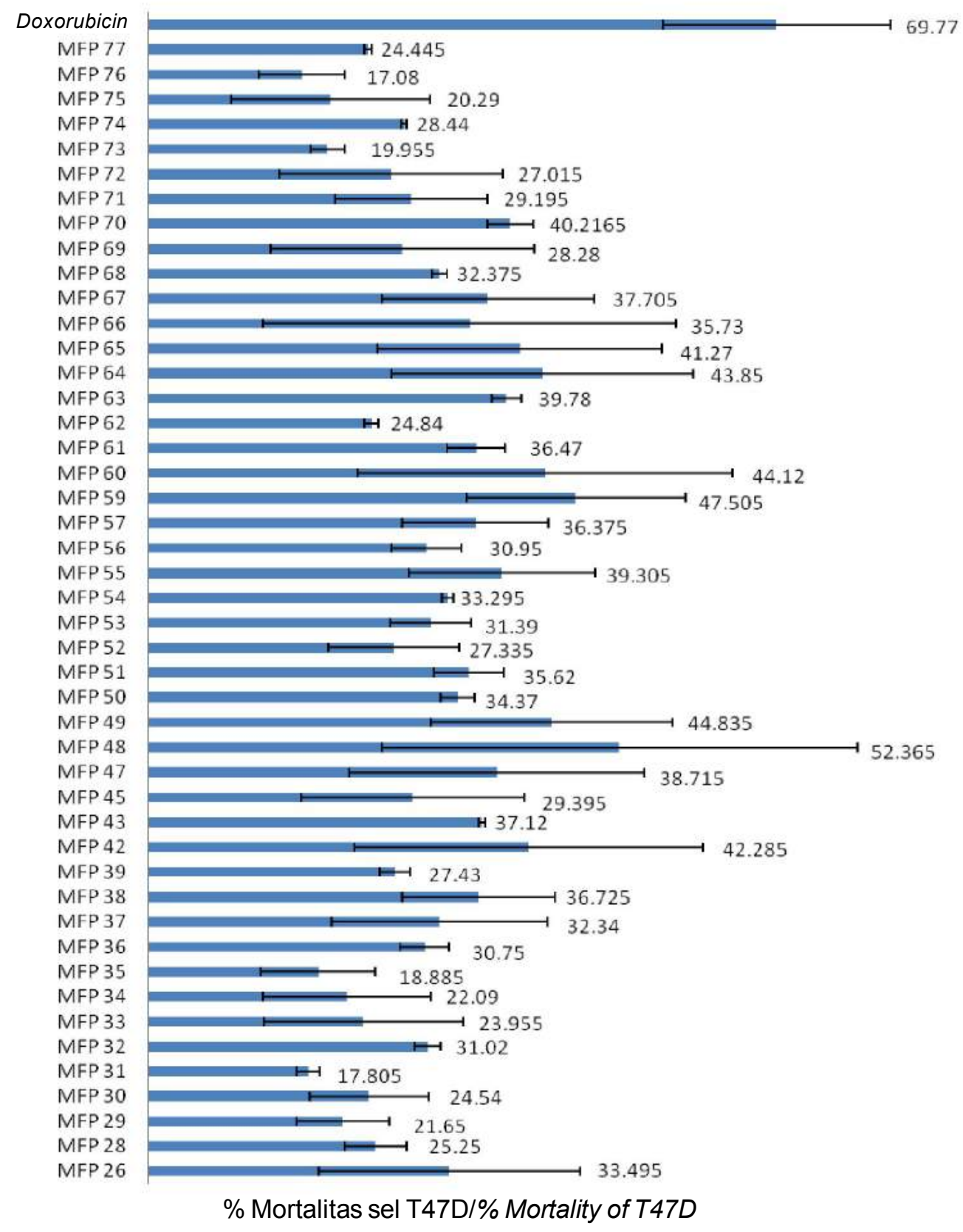

Gambar 2. Mortalitas sel T47D yang diberi perlakuan ekstrak kasar kapang MFP pada konsentrasi $30 \mu \mathrm{g} /$ $\mathrm{mL}$.

Figure 2. Mortality of T47D cell lines which were treated with $30 \mu \mathrm{g} / \mathrm{mL}$ of MFP-fungi crude extract. 
merupakan isolat kapang yang memang berpotensi untuk dikembangkan. Pada Gambar 2 dan 4 tampak standar deviasi dari dua kali hasil uji MTT relatif cukup besar. Hal tersebut kemungkinan disebabkan ekstrak kasar kapang yang diujikan masih berupa campuran dari berbagai macam senyawa metabolit sekunder yang dihasilkan isolat kapang dan berbagai komponen media pertumbuhan yang ikut terekstrak, misalnya garam maupun protein ('pengotor' esktrak).

Uji MTT merupakan metode yang cepat dan cukup sensitif sehingga banyak digunakan untuk studi proliferasi maupun sitotoksisitas sel. Uji ini merupakan uji kolorimetri berdasarkan pada pemecahan garam tetrazolium (MTT) berwarna kuning yang diubah oleh enzim suksinat dehidrogenase yang dihasilkan oleh sel hidup menjadi kristral biru-formazan (Zachary, 2003). Dengan demikian, jumlah formazan yang dihasilkan akan proporsional dengan jumlah sel hidup dalam uji MTT. Untuk meningkatkan validitas data hasil uji sitotoksisitas, setiap hasil penghitungan angka mortalitas sel tumor kemudian dikonfirmasi dengan gambaran morfologi sel tumor pada uji tersebut. Ekstrak kapang yang tergolong aktif akan didukung oleh gambaran sel uji yang mengalami perubahan morfologi atau gambaran kepadatan sel yang secara signifikan lebih rendah dibandingkan kontrol sel.

Beberapa literatur menggunakan kriteria yang berbeda dalam mengkategorikan 'sampel aktif' dalam tahap bioprospeksi antitumor yang di kerjakan. Dalam penelitian bioprospeksi senyawa antikanker dari tanaman khas Brasil yang dikerjakan oleh Mans et al. (2000), sampel dikategorikan aktif apabila ekstrak kasar yang diujikan pada konsentrasi $50 \mu \mathrm{g} / \mathrm{mL}$ mampu menghambat pertumbuhan $\geq 50 \%$ sel tumor yang diujikan. Sementara itu, Carballo et al. (2002) mengkategorikan suatu sampel sebagai aktif apabila pada konsentrasi $30 \mu \mathrm{g} / \mathrm{mL}$ ekstrak kasar sampel tersebut menyebabkan kematian $\geq 50 \%$ sel tumor yang diujikan. Pada penelitian ini isolat kapang dikategorikan sebagai sampel aktif apabila pada konsentrasi tunggal $30 \mu \mathrm{g} / \mathrm{mL}$ ekstrak kasar kapang tersebut mampu membunuh $\geq 40 \%$ sel lestari tumor.

Dari 46 isolat kapang yang diuji, terdapat delapan isolat kapang yang tergolong aktif terhadap sel tumor payudara-T47D (Gambar 2), yaitu MFP 42 (42,28\%), MFP 48 (52,36\%), MFP 49 (44,83\%), MFP $59(47,5 \%)$, MFP 60 (44,12\%), MFP 64 (43,85\%), MFP 65 $(41,27 \%)$, dan MFP 70 (40,21\%). Gambaran morfologi sel tumor T47D yang diberi perlakuan ekstrak kapang MFP disajikan pada Gambar 3.

Sel tumor T47D merupakan sel tumor kelenjar susu yang mengekspresikan oncogene WNT7B dan mutant protein p53 (Anon., 2011). Sel lestari tumor T47D tersebut diisolasi dari seorang perempuan penderita kanker kelenjar susu yang berusia 54 tahun (Anon., 2011). Ketika dikultur, sel T47D tumbuh melekat di dasar sumuran mikroplat. Pada Gambar 3 tampak kepadatan sel tumor payudara T47D yang diberi perlakuan ekstrak kapang aktif MFP 42, 48, 49, 59, 60, 64, 65, dan 70 lebih rendah dibandingkan dengan kontrol sel (negatif). Gambaran jaringan tumor T47D pada kontrol sel tampak sangat rapat dan tidak menyisakan sedikitpun ruang kosong di dasar mikroplat (100\% confluent). Sementara itu, gambaran jaringan tumor T47D yang diberi perlakuan ekstrak kapang aktif menjadi renggang, banyak ruang kosong di dasar mikroplat yang disebabkan banyaknya sel T47D yang mati akibat perlakuan ekstrak kapang tersebut.

HepG2 merupakan sel lestari tumor hati yang diisolasi dari remaja laki-laki yang menderita hepatocellular carcinoma pada organ hatinya (Anon., 2011'b). Seperti halnya sel T47D, sel HepG2 tumbuh melekat membentuk lapisan tunggal (monolayer) di dasar sumuran mikroplat ketika dikultur. Dari 46 isolat kapang yang diujikan, terdapat satu isolat kapang yang tergolong aktif terhadap tumor HepG2 yang diujikan, yaitu ekstrak isolat kapang MFP-64. Pada konsentrasi uji $30 \mu \mathrm{g} / \mathrm{mL}$, ekstrak kasar kapang MFP 64 mampu menyebabkan mortalitas sel tumor HepG2 sebesar $40,22 \%$.

Di antara delapan isolat kapang yang tergolong aktif terhadap sel tumor payudara T47D (Gambar 2 dan 3), hanya isolat MFP-64 yang juga tergolong aktif terhadap sel tumor hati HepG2. Pada konsentrasi uji $30 \mu \mathrm{g} / \mathrm{mL}$, ekstrak kasar kapang MFP-64 mampu mengakibatkan mortalitas sel T47D sebesar $43,85 \%$ dan HepG2 sebesar 40,22\%. Bioaktivitas antitumor isolat kapang MFP 42, 48, 49, 59, 60, 65, dan 70 tampaknya bersifat selektif terhadap sel tumor payudara T47D, sehingga ketika diujikan terhadap jenis sel tumor HepG2 tidak memberikan bioaktivitas yang berarti.

Selain sebagai antitumor, metabolit aktif dari kapang yang berasosiasi dengan biota laut juga dilaporkan mempunyai berbagai bioaktivitas lain, di antaranya sebagai antivirus, misalnya senyawa Sansalvamide A yang diisolasi dari kapang Fusarium sp. mampu menghambat virus pathogen Molluscum contagiosum (Hwang et al., 1999); sebagai antibakteri, misalnya senyawa baru chlorinated benzophene yang diisolasi dari kapang laut Pestalotia sp. memiliki potensi sebagai antibiotik terhadap $S$. aureus yang resisten terhadap methicillin (Cueto et al., 2001); maupun sebagai antikapang, misalnya senyawa trichodermamide $B$ yang diisolasi dari kapang laut Trichoderma virens mempunyai aktivitas penghambatan terhadap kapang $C$. albicans yang resisten terhadap amphotericin (Liu et al., 2003). Hasil 


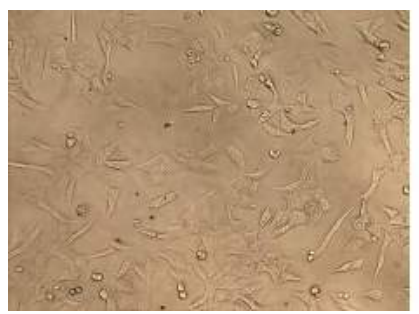

MFP 42

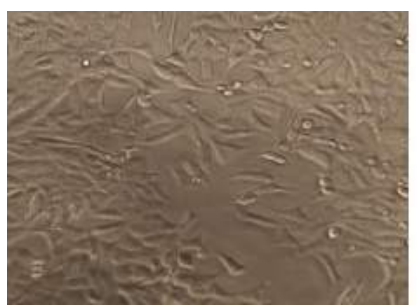

MFP 59

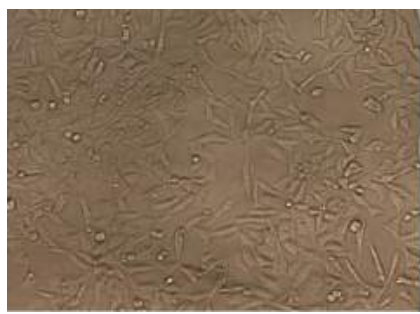

MFP 65

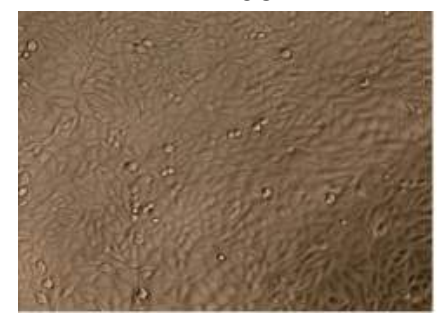

Kontrol negatif (kontrol sel) Negative control (cell control)

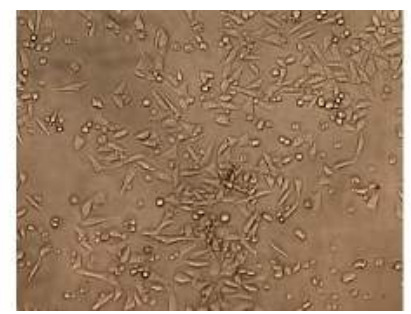

MFP 48

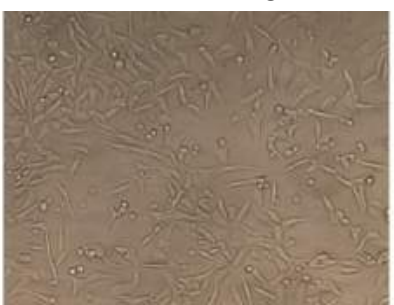

MFP 60

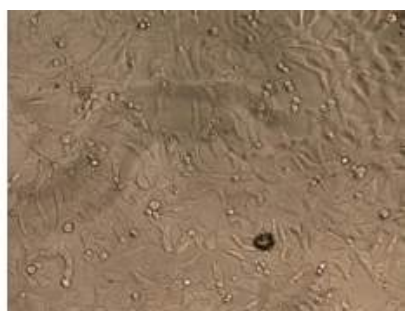

MFP 70

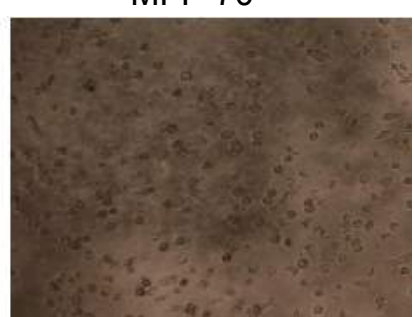

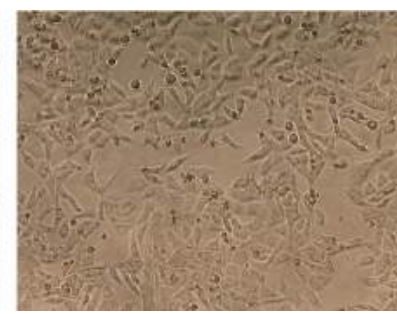

MFP 49

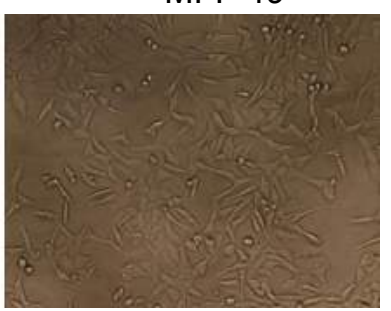

MFP 64

Kontrol positif/Positive control

Doxorubicin 5 ppm

Gambar 3. Gambar morfologi sel T47D setelah diberi perlakuan ekstrak kasar kapang MFP-42, 48, 49, 59, $60,64,65$, dan 70 dibandingkan dengan kontrol sel (kontrol negatif dan kontrol positif).

Figure 3. Morphology representation of T47D cells treated with marine-derived fungi MFP 42, 48, 49, 59, 60, 64, 65 and 70 crude extract compared to cell control (negative control and positive control).

penelitian ini memperlihatkan bahwa kapang yang berasosiasi dengan biota laut merupakan sumber yang potensial sebagai penghasil senyawa-senyawa metabolit baru dengan berbagai fungsi farmakologis yang dapat dikembangkan sebagai obat berbagai penyakit.

Produksi dan kualitas metabolit sekunder yang dihasilkan suatu organisme sangat dipengaruhi oleh wilayah geografis perairan tempat organisme tersebut hidup. Seperti yang dilaporkan oleh Schulz et al. (2008), kapang laut Dendryphiella spp. yang diisolasi dari berbagai iklim dan lokasi subtropis berbeda ternyata profil metabolitnya (HPLC-DAD) berbeda. Hal tersebut kemungkinan disebabkan oleh adanya perbedaan kondisi abiotik perairan di wilayah geografis yang berbeda tersebut. Menurut Yu \& Keller (2005), kondisi abiotik lingkungan seperti suhu yang bervariasi, salinitas, tekanan air laut yang tinggi serta ketersediaan nutrisi yang berbeda di setiap perairan berpengaruh terhadap produksi metabolit sekunder suatu organisme. Dengan demikian, perairan tropis Indonesia dan kekayaan biodiversitasnya yang sangat tinggi namun relatif belum tereksplorasi, menjadi tantangan sekaligus peluang besar untuk mendapatkan senyawa metabolit baru dengan fungsi farmakologis potensial melalui penelitian-penelitian bioprospeksi. 


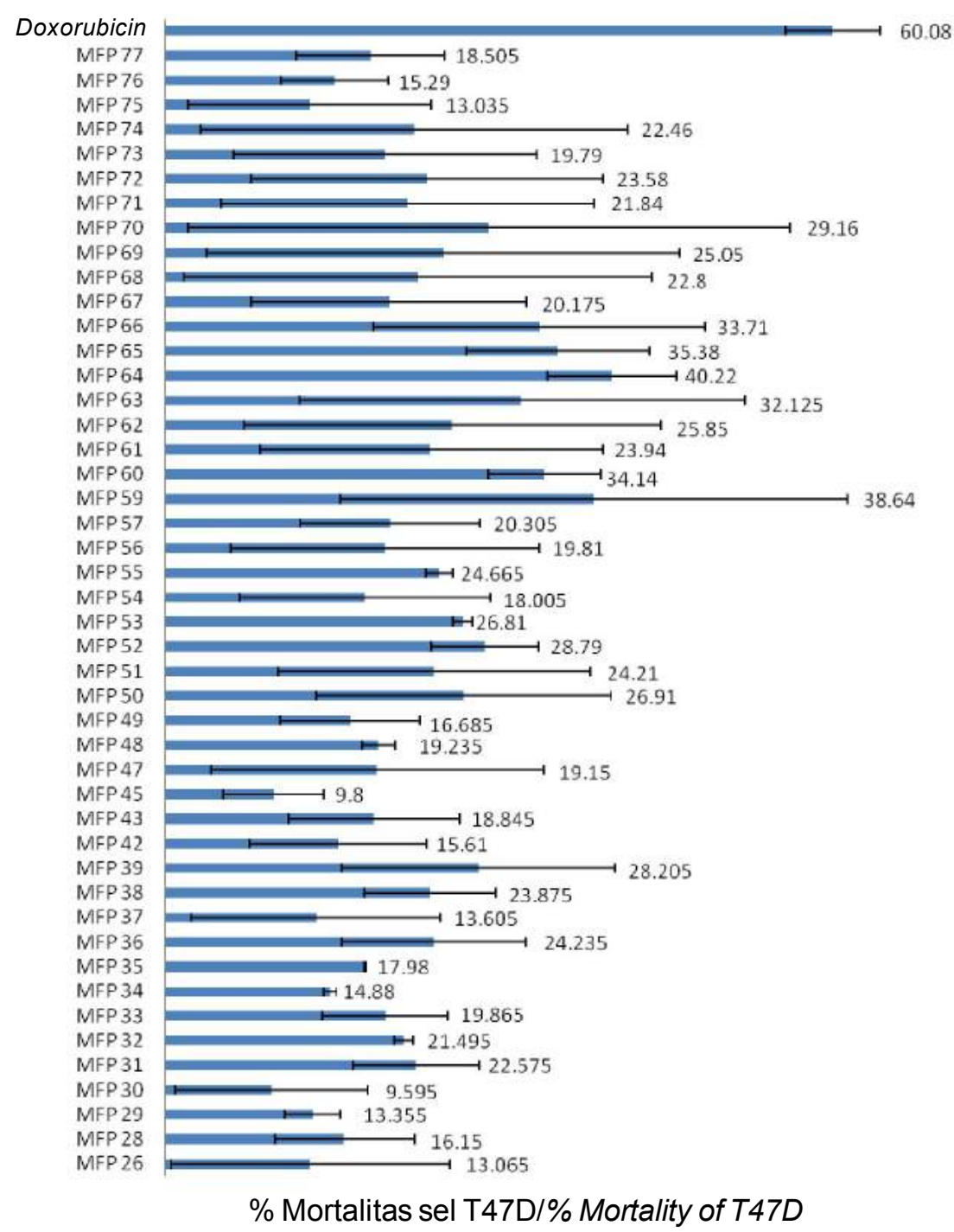

Gambar 4. Mortalitas sel HePG2 yang diberi perlakuan ekstrak kasar kapang MFP pada konsentrasi $30 \mu \mathrm{g} /$ $\mathrm{mL}$.

Figure 4. Mortality of HepG2 cell lines which were treated with $30 \mu \mathrm{g} / \mathrm{mL}$ of MFP-fungi crude extract.

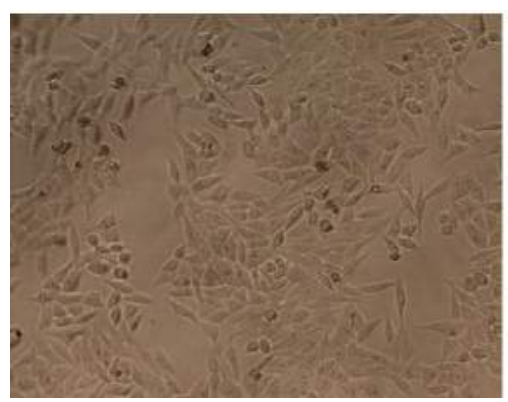

MFP 64

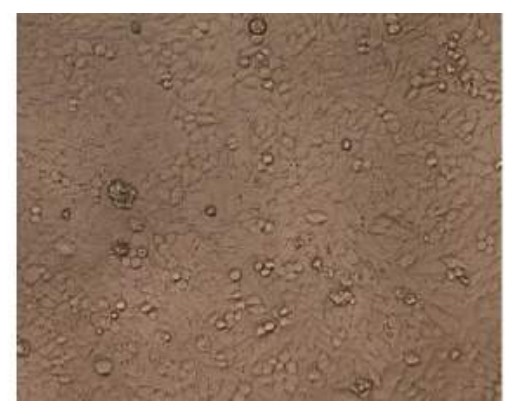

Kontrol negatif (kontrol sel)/ Negative control (cell control)

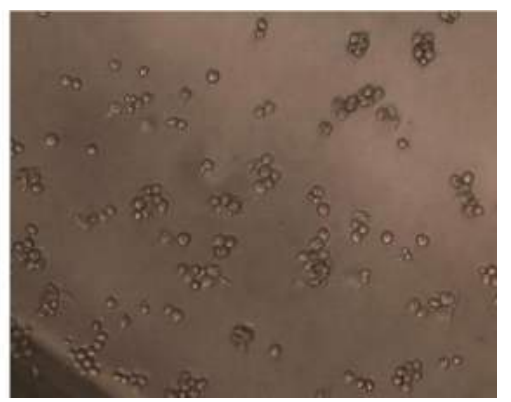

Kontrol positif/Positive control Doxorubicin 5 ppm

Gambar 5. Gambar morfologi sel HepG2 setelah diberi perlakuan ekstrak kasar kapang MFP-64 dibandingkan dengan kontrol sel (kontrol negatif) dan kontrol positif.

Figure 5. Morphology representation of HepG2 cells treated with marine-derived fungi MFP-64 crude extract compared to cell control (negative control) and positive control. 


\section{KESIMPULAN}

Kegiatan penelitian bioprospeksi kapang yang berasosiasi dengan spons dan karang lunak asal Taman Nasional Laut Kepulauan Seribu berhasil mendapatkan 7 isolat kapang yang aktif sebagai antitumor payudara (T47D), yaitu isolat MFP 42, MFP 48, MFP 49, MFP 59, MFP 60, MFP 65, dan MFP 70 dan 1 isolat kapang (MFP 64) yang aktif sebagai antitumor payudara (T47D) dan aktif sebagai antitumor liver (HepG2).

\section{UCAPAN TERIMA KASIH}

Penulis mengucapkan terima kasih kepada Gintung Patantis yang telah membantu dalam pengambilan sampel hospes spons dan karang lunak di Perairan Taman Nasional Laut Kepulauan Seribu untuk bahan penelitian.

\section{DAFTAR PUSTAKA}

Anonymous. 2011'a. ATCC-product description-T47D. http://www.cicams.ac.cn/marker/cell\%20lines/T47D.htm. Diakses pada tanggal 15 Desember 2011.

Anonymous. 2011 . ATCC-product description-HepG2. http://www.atcc.org/ATCCAdvancedCatalogSearch/ Product Details/tabid/452/Default. a s $p x$ ? A T C C N u $m=C R L-10741$ \& Template $=$ cellBiology. Diakses pada tanggal 15 Desember 2011.

Anonim. 2012. GLOBOCAN 2008. http:// www.globocan.iarc.fr/. Diakses pada tanggal 5 Maret 2012.

Berdy, J. 2005. Bioactive microbial metabolites. J. Antibiot. 58(1): 1-26.

Bhadury, P., Mohammad, B.T., and Wright, P.C. 2006. The current status of natural products from marine fungi and their potential as anti-infective agents. J. Ind Microbiol Biotechnol. 33: 325-337.

Bhatnagar, I. and Kim, S. 2010. Marine antitumor drugs: status, shortfalls and strategies. Mar. Drugs. 8: 2702 2720.

Bode, H.B., Bethe, B., Hofs, R., and Zeeck, A. 2002.Big effects from small changes: possible ways to explore nature's chemical diversity. ChemBioChem. 3: 619627.

Bugni, T.S. and Ireland, C.M. 2004. Marine-derived fungi: a chemically and biologically diverse group of microorganisms. Nat. Prod. Rep. 21: 143-163.

Carballo, J.L., Hernandez-Inda, Z.L., Perez, P., and GarciaGravalos, M.D. 2002. A comparison between two brine shrimp assay to detect in vitro cytotoxicity in marine natural product (Methodology Article). BMC Biotechnology. 2: 1-5.
Chasanah, E., Januar, H.I., Irianto, H.E., Bourne, D., Liptrot, C., and Wright, A. 2009. Screening of anticancer activity of fungi derived from Indonesian marine sponges. J. Marine and Fisheries Postharvest and Biotechnology Special Edition in Conjuction with World Ocean Conference 2009. 4: 1-8.

Cueto, M., Jensen, P.R., Kauffman, C., Lobkovsky, E., and Clardy, J. 2001. Pestalone, a new antibiotic produced by a marine fungus in response to bacterial challenge. J. Nat. Prod. 64: 1444-1446.

Hwang, Y., Rowley, D., Gertsch, J., Fenical, W. and Bushman, F. 1999. Mechanism of inhibition of a poxvirus topoisomerase by the marine natural product sansalvamide A. Mol. Pharmacol. 55: 10491053

Holler, U., Wright, A.D., Matthee, G.F., Konig, G. M., Draeger, S., Aust, H., and Schulz, B. 2000. Fungi from marine sponges: diversity, biological activity and secondary metabolites. Mycol. Res. 104(11): 1354-1365.

Kjer, J., Debbab, A., Aly, H., and Proksch, P. 2010. Methods for isolation of marine-derived endophytic fungi and their bioactive secondary products. Nature Protocols. 5(3): 479-490.

Liu, Z. Jensen, P.R., and Fenical, W. 2003. A cyclic carbonate and related polyketides from a marinederived fungus of the genus Phoma. Phytochemistry. 64: 571-574.

Mans, D.R.A., Rocha, A.B, Schwartsman, G. 2000. Anticancer drug discovery and development in Brazil: targeted plant collection as a rational strategy to acquire candidate anti-cancer compounds. The Oncologist. 5: 185-198

Nursid, M., Chasanah, E., Murwantoko, and Wahyuono, S. 2011. Isolasi senyawa sitotoksik dari kapang Emericella nidulans. Jurnal Pascapanen dan Bioteknologi Kelautan dan Perikanan. 6 (2): 119130.

Pratitis, A., Patantis, G., Mangunwardoyo, W., and Chasanah, E. 2010. Produksi senyawa bioaktif dari Aspergillus ustus MFW 26-08 yang berasosiasi dengan spons laut dalam berbagai media. Jurnal Pascapanen dan Bioteknologi Kelautan dan Perikanan. 5(2): 93-102.

Schulz, B., Draeger, S., dela Cruz, T.E., Rheinheimer, K.S., Loesgen, S., Bitzer, J., Schloerke, O., Zeeck, A., Kock, I., Hussain, H., Dai, J., and Krohn, K. 2008. Screening strategies for obtaining novel, biologically active, fungal secondary metabolites from marine habitats. Botanica Marina. 51: 219-234.

$\mathrm{Yu}$, J.H. and Keller, N. 2005. Regulation of secondary metabolism in filamentous fungi. Annu. Rev. Phytopathology. 43: 437-458.

Zachary, I. 2003. Determination of cell number. In Hughes, D. and Mehmet, H. (eds.). Cell proliferation and apoptosis. BIOS Scientific Publisher Limited. 